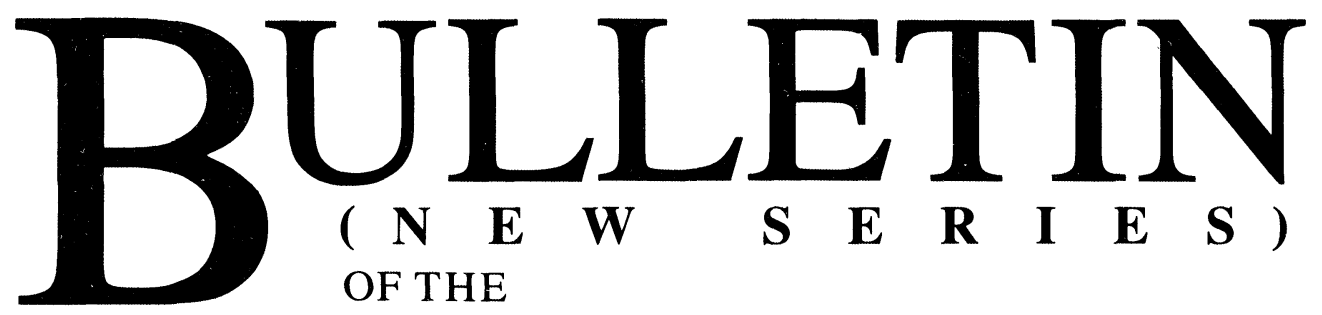

A M E R I C A N M A T H E M A T I C A L S O C I E T Y

\title{
EDITORS
}

Richard S. Palais, Research Expository Papers

Murray Protter, Book Reviews

Roger E. Howe, Research Announcements

PROVIDENCE, RHODE ISLAND USA

ISSN 0273-0979 


\section{BULLETIN (New Series) of the American Mathematical Society}

BULLETIN (New Series) contains articles of the types listed below. Information on Manuscript, Proof, and Copying can be found at the back of this journal.

\section{RESEARCH-EXPOSITORY PAPERS}

These are, by definition, papers which present a clear and insightful exposition of significant aspects of contemporary mathematical research. Gibbs lectures and retiring presidential addresses will be included in this section. Manuscripts should be submitted to Professor Richard S. Palais, Department of Mathematics, Brandeis University, Waltham, MA 02154-9110.

\section{RESEARCH ANNOUNCEMENTS}

The purpose of this department is to publish quickly and disseminate widely significant new mathematics. A Research Announcement should be designed to communicate its contents to a broad mathematical audience and should meet high standards for clarity as well as mathematical content. It should have a substantial introductory section addressed to non-experts describing the motivation, background and significance of the results announced. Following the statement of results, there should follow a sketch of proofs which may be addressed to experts. Having colleagues, including non-experts, proofread a manuscript can be an effective way to improve readability. An announcement should normally not exceed 7 journal pages. Authors should send five (5) copies of each manuscript to Roger Howe, Department of Mathematics, Yale University, Box 2155, Yale Station, New Haven, CT 06520. Deadlines for submission are: August 15 for the January issue; November 1 for April; February 1 for July; and May 1 for October. (These deadlines assume ideal conditions; difficulties in processing, including manuscript defects, may cause deviations from this schedule.)

Subscription Information: BULLETIN (New Series) of the American Mathematical Society is published quarterly. Subscription prices for Volumes 22 and 23 (1990) are \$174 list, \$139 institutional member, $\$ 104$ individual member. The subscription price for members is included in the annual dues. A late charge of $10 \%$ of the subscription price will be imposed upon orders received from nonmembers after January 1 of the subscription year. Subscribers outside the United States and India must pay a postage surcharge of $\$ 8.00$; subscribers in India must pay a postage surcharge of $\$ 13.00$. Combination paper and microfiche subscription prices are $\$ 231$ list, $\$ 185$ institutional member. Microfiche of each issue will be mailed the fastest way before the camera copy is sent to the printer. Microfilm subscriptions may be purchased from University Microfilms International, 300 North Zeeb Road, Ann Arbor, MI 48106.

Back Number Information: Back number prices (per volume) for BULLETIN (New Series) Volume 1 are \$64 list, \$52 institutional member; for Volumes 2-9 \$32 list, \$26 institutional member; for Volumes $10-$ $11 \$ 40$ list, \$32 institutional member; for Volumes 12-13\$96 list, \$77 institutional member; for Volumes 14-15 \$118 list, \$94 institutional member; for Volumes 16-19 \$126 list, \$101 institutional member; for Volumes 20-21 \$129 list, \$103 institutional member. Back number prices (per volume) of Volumes 1-84 for the BULLETIN of the American Mathematical Society which ceased publication in 1978 are $\$ 64$ list, $\$ 52$ institutional member. Back volumes may be purchased on microfilm or microfiche from University Microfilms International, 300 North Zeeb Road, Ann Arbor, MI 48106.

Subscriptions and orders for publications should be addressed to the American Mathematical Society, P.O. Box 1571, Annex Station, Providence, RI 02901-9930. All orders must be accompanied by payment. Other correspondence should be addressed to the Society at P.O. Box 6248, Providence, RI 02940.

BULLETIN (New Series) of the American Mathematical Society (USPS 075640) is published quarterly by the American Mathematical Society at 201 Charles Street, Providence, RI 02904-2213. Secondclass postage is paid at Providence, Rhode Island and additional mailing offices. Postmaster: Send address changes to BULLETIN, American Mathematical Society, P.O. Box 6248, Providence, RI 02940-6248.

Copyright (C) American Mathematical Society 1990. All rights reserved.

Information on copying and reprinting can be found at the back of this journal.

Printed in the United States of America

The paper used in this book is acid-free and falls within the guidelines established to ensure permanence and durability. @

This publication was typeset using $A M S-T_{E} X$,

the American Mathematical Society's TEX macro system.

$10987654321 \quad 959493929190$ 